\title{
Communication
}

\section{Evidence for the Formation of Difluoroacetic Acid in Chlorofluorocarbon-Contaminated Ground Water}

\author{
Ute Dorgerloh*(D), Roland Becker ${ }^{\mathbb{D}}$ and Melanie Kaiser \\ Bundesanstalt für Materialforschung und -prüfung, BAM, 12489 Berlin, Germany; roland.becker@bam.de (R.B.); \\ melanie.kaiser@campus.tu-berlin.de (M.K.) \\ * Correspondence: ute.dorgerloh@bam.de; Tel.: +49-308-1045-937 \\ Academic Editor: Matthias Koch \\ Received: 20 February 2019; Accepted: 12 March 2019; Published: 15 March 2019 \\ updates

\begin{abstract}
The concentrations of difluoroacetic acid (DFA) and trifluoroacetic acid (TFA) in rainwater and surface water from Berlin, Germany resembled those reported for similar urban areas, and the TFA/DFA ratio in rainwater of 10:1 was in accordance with the literature. In contrast, nearby ground water historically contaminated with 1,1,2-trichloro-1,2,2-trifluoroethane (R113) displayed a TFA/DFA ratio of 1:3. This observation is discussed versus the inventory of microbial degradation products present in this ground water along with the parent R113 itself. A microbial transformation of chlorotrifluoroethylene (R1113) to DFA so far has not been reported for environmental media, and is suggested based on well-established mammalian metabolic pathways.
\end{abstract}

Keywords: fluoroacetic acid; DFA; TFA; rainwater; ground water; degradation of refrigerants

\section{Introduction}

Trifluoroacetic acid (TFA) is very stable in the environment with an estimated half-life of several hundreds of years [1,2] and is found worldwide in oceans [3] and water bodies [4], though no accumulation in biota has been observed [2]. A total TFA release of 20,650,000 metric tons by 2050 to the global environment via abiotic breakdown of refrigerants containing a trifluoromethyl moiety [5] has been estimated [2]. In addition, a natural oceanic source for TFA has been suggested on the basis of concentration patterns [3,6].

Little is known about the origin and behavior of environmental difluoroacetic acid (DFA) and its natural source has not been identified to the best of our knowledge. Significant DFA levels were found in the Detroit river [4] and the urban atmosphere [7]. The limited literature on DFA formation suggests reductive defluorination of TFA to DFA and further to monofluoroacetic acid under certain anaerobic conditions [8,9]. The relevance of DFA formation during the pyrolysis of fluoropolymers $[10,11]$ as a source for environmental DFA levels is unclear, and the formation of DFA by the oxidative metabolization of compounds such as the pesticide flupyradifurone containing the difluoromethyl moiety [12] appears negligible compared to currently observed environmental DFA concentrations.

A survey of short-chain fluorocarboxylic acids in urban aqueous environments revealed compartment-depending differing levels and ratios of TFA and DFA. In the following, this observation is outlined and discussed regarding the potential origin of DFA in ground water with historic chlorofluorocarbon (CFC) contamination.

\section{Results}

Table 1 reveals the concentrations of TFA and DFA in rainwater collected with a temporal interval of $24 \mathrm{~h}$. Assuming a depuration effect by the first rainfall after a longer dry period, the TFA concentration decreased in the consecutive rainfall. This TFA concentration range resembled 
the average concentration levels observed in the USA [13]. The TFA:DFA ratio of about 10:1 in both rainwater samples correlates well with the airborne TFA:DFA ratio reported for urban areas in Ontario, Canada [7]. Both surface waters contain considerable TFA levels, but notably no detectable DFA. Similar observations were made along the Detroit river, where TFA levels always exceeded DFA levels, which were partly not detectable [4].

Table 1. Trifluoroacetic acid (TFA) and difluoroacetic acid (DFA) concentrations in rainfall and surface water (means and relative standard deviations, $n=2$ ).

\begin{tabular}{|c|c|c|}
\hline Water Sample & $\begin{array}{c}\text { TFA } \\
\text { (ng/L) }\end{array}$ & $\begin{array}{c}\text { DFA } \\
\text { (ng/L) }\end{array}$ \\
\hline Rainwater $1: 1 \mathrm{~h}$ of rainfall after a long dry period & $1556^{a}$ & $151^{a}$ \\
\hline Rainwater 2: after $12 \mathrm{~h}$ of heavy rainfall & $370(3.7 \%)$ & $43(4.4 \%)$ \\
\hline Surface water: Teltow canal & $1908(0.9 \%)$ & n.d. ${ }^{b}$ \\
\hline Surface water: Havel lake & $676(7.1 \%)$ & n.d. ${ }^{b}$ \\
\hline
\end{tabular}

The contaminated ground water contained a TFA level similar to the surface waters but with significantly higher DFA levels (Table 2). The opposite ratios of TFA and DFA in rainwater and ground water are depicted in Figure 1.

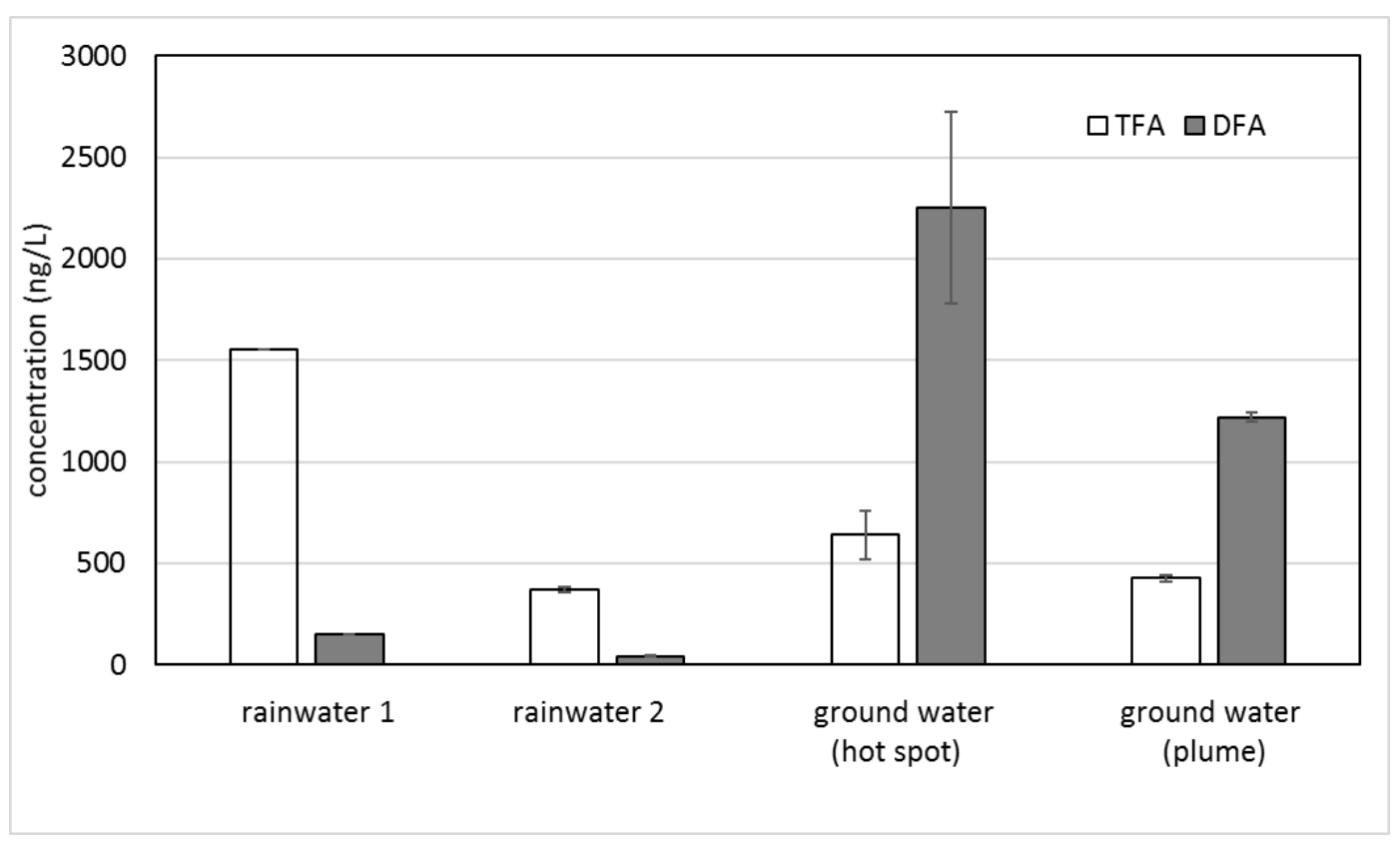

Figure 1. Concentrations of TFA and DFA in rainwater and ground water. Error bars show standard deviation $(n=2)$.

Tables 1 and 2 and Figure 2 show relatively similar levels of TFA in rainwater, lake water, and ground water. The high TFA concentration in the first rainfall after a long dry period (rainwater 1) and the sewer drain sampling point at the Teltow canal are consistent with a long accumulation period of air contaminants. For the TFA concentration in rainwater 2 collected after a first depuration (rainwater 1), surface water (Havel lake) and the ground water samples displayed a largely similar level of around $500 \mathrm{ng} / \mathrm{L}$ (from 370 to $676 \mathrm{ng} / \mathrm{L}$ ). On the other hand, the DFA concentrations in the ground water samples with a maximum at the contamination hot spot considerably exceeded those of the rainwater. Additionally, the sum of TFA and DFA in the ground water did not correlate with the input from the rain and surface water. Therefore, another source for DFA is likely. 
An assessment of this observation may be supported by an inventory of fluorine-containing ground water pollutants at this site (Table 2).

Table 2. Concentration of TFA, DFA, and chlorofluorocarbons (CFCs) in the ground water samples, means and relative standard deviations (TFA and DFA: $n=2$; CFCs: $n=6$ ). R113: 1,1,2-trichloro-1,2,2trifluoroethane; R123a: 1,2-dichloro-1,2,2-trifluoroethane; R1113: chlorotrifluoroethene.

\begin{tabular}{lccccc}
\hline Ground Water Sample & $\begin{array}{c}\text { TFA } \\
(\mathbf{n g} / \mathrm{L})\end{array}$ & $\begin{array}{c}\text { DFA } \\
(\mathbf{n g} / \mathrm{L})\end{array}$ & $\begin{array}{c}\text { R113 } \\
(\mu \mathrm{g} / \mathrm{L})\end{array}$ & $\begin{array}{c}\text { R123a } \\
(\mu \mathrm{g} / \mathrm{L})\end{array}$ & $\begin{array}{c}\text { R1113 } \\
(\mu \mathrm{\mu g} / \mathrm{L})\end{array}$ \\
\hline Contamination hot spot & 639 & 2249 & 4806 & 27.1 & 68.4 \\
& $(19 \%)$ & $(21 \%)$ & $(5 \%)$ & $(2 \%)$ & $(3 \%)$ \\
Contamination plume & 425 & 1220 & 3315 & 10.1 & 28.2 \\
& $(3.3 \%)$ & $(1.8 \%)$ & $(3 \%)$ & $(4 \%)$ & $(3 \%)$ \\
\hline
\end{tabular}

The pollution monitoring at this site supervised by the authors' institute over two decades revealed 1,1,2-trichloro-1,2,2-trifluoroethane (R113) as sole CFC. Table 2 comprises the average R113 concentrations and the concentrations of 1,2-dichloro-1,2,2-trifluoroethane (R123a) and chlorotrifluoroethene (R1113) as quantified by headspace-GC-MS according to ISO 20595:2018 [14].

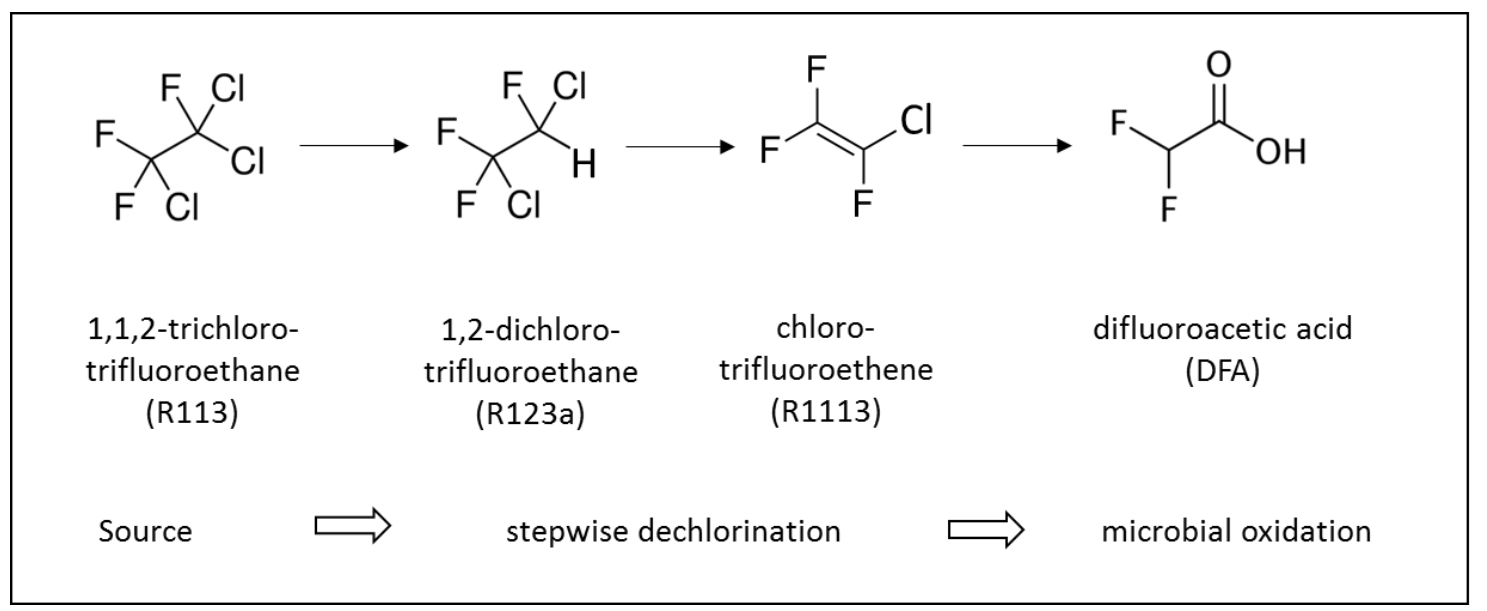

Figure 2. Reductive dechlorination of R113 to R1113 according to Balsiger et al. [15] as observed, and the proposed hydrolysis of R1113 to DFA.

Figure 2 depicts the reductive dechlorination sequence of R113 via R123a to R1113 observed under anaerobic conditions in aquifers [15]. The high concentration of DFA in the contaminated ground water suggests a transformation of R1113 to DFA which, to the best of our knowledge, has not yet been reported under environmental conditions.

However, the detoxification pathway of chlorinated 1,2-difluoroethene in rats involves the formation of glutathione-S-conjugates in hepatic cytosol and microsomes [16,17]. In the case of 1,1-dichloro-2,2-difluoroethene, the subsequent hydrolysis to DFA has been reported [18], while in the case of chlorotrifluoroethene (R1113) the respective glutathione-S-conjugate formation was shown but its further fate was not investigated [16]. Nevertheless, DFA is a likely metabolization product of R1113.

Note that glutathione is known to be involved in metabolization reactions of xenobiotics in some microbes as well [19], supporting the idea of the microbial origin of TFA via this pathway.

On the other hand, the abiotic degradation of TFA in water is very slow [20]. The relevance of the reported anaerobic microbial degradation of TFA in laboratory experiments [9,21] for the environmental fate of TFA is not fully clarified [22], and does support reductive defluorination as an alternative source of DFA formation. 
The TFA concentration levels at the investigated ground water sites are similar to those of surface water. The local geology displays a low permeability of barrier layers and hydrodynamic flow direction from the canal towards the ground water site. This, and the absence of $\mathrm{CFCs}$ containing the $\mathrm{CF}_{3}$-group in the ground water as a potential source for TFA, suggest a surface water origin of the TFA in the ground water.

The atmospheric origin of DFA found in the rainwater has to remain an open question. As significant volatilization of TFA and DFA from water bodies can be excluded due to their physicochemical characteristics [23], the possible options are atmospheric oxidation of some difluoromethyl compounds or reductive defluorination of TFA that has not been observed in the atmosphere so far.

\section{Materials and Methods}

\subsection{Chemicals and Reagents}

Methanol (Picograde) was purchased from LGC Promochem (Teddington, UK), ammonium carbonate and concentrated sulfuric acid were from J.T. Baker (Schwerte, Germany), difluoroacetic acid (98\%) was supplied by Acros Organics BVBA (Geel, Belgium), and trifluoroacetic acid (99\%) was from Alpha Aesar/Thermo Fischer (Karlsruhe, Germany).

\subsection{Sample Preparation}

The water samples were buffered at $\mathrm{pH} 9$ and dried. The fluoroacetic acids were derivatized with methanol to their methyl esters using a modified literature procedure [24].

Each water sample (1 L) was buffered with ammonium carbonate at $\mathrm{pH} 9$ to ensure that TFA was retained completely as acetate during evaporation of the water until the samples were dry. Evaporation was performed in three steps: From $1 \mathrm{~L}$ to $50 \mathrm{~mL}$ using a recirculating dryer at $70{ }^{\circ} \mathrm{C}$, from $50 \mathrm{~mL}$ to $5 \mathrm{~mL}$ in a heated nitrogen concentrator at $55^{\circ} \mathrm{C}$ (SuperVap 12, FMS, Watertown, MA, USA), and finally after transfer to a $10 \mathrm{~mL}$ headspace vial by lyophilization in a freeze drier (LYOVA GT2, SRK Systemtechnik $\mathrm{GmbH}$, Riedstadt, Germany). Each vial containing a dried sample was crimped and cooled down to $-28{ }^{\circ} \mathrm{C}$. Then, $800 \mu \mathrm{L}$ of a mixture of $\mathrm{H}_{2} \mathrm{SO}_{4}$ and methanol $(3: 1, v: v)$ were added with a $1000 \mu \mathrm{L}$ syringe through the closed septum. The formed fluoroacetic acid methyl esters were volatile and could be determined by gas chromatography from the headspace. For method calibration in a range from 1 to $4000 \mathrm{ng}$ absolute per sample, different amounts from DFA and TFA stock solutions in methanol were added to closed headspace vials through the septa. Then, the derivatization was done as described above. The recovery rate for the drying procedure at 20 and $2000 \mathrm{ng} / \mathrm{L}$ was between $70 \%$ and $100 \%$, the relative standard deviation $(n=3)$ was between $10 \%$ and $17 \%$.

\subsection{Determination of the Methyl Esters of Difluoro- and Trifluoroacetic Acid by Gas Chromatography-Mass Spectrometry}

An HP7890B gas chromatograph coupled with an HP5977A mass selective detector (MSD, Agilent, Santa Clara, CA, USA) and a MPS2XL autosampler (Gerstel, Mülheim, Germany) was used for quantification of TFA and DFA by analyzing their methyl esters. Gas chromatographic separation was achieved using a VF624 standard capillary column $(60 \mathrm{~m} \times 320 \mu \mathrm{m} \times 1.8 \mu \mathrm{m})$ (Agilent). After conditioning of the headspace vial containing the methyl esters $\left(70^{\circ} \mathrm{C}, 15 \mathrm{~min}\right), 1 \mathrm{~mL}$ of the headspace volume was injected into the gas chromatograph (split 1:5). The oven program started at $40{ }^{\circ} \mathrm{C}$ (held for $10 \mathrm{~min})$ and was ramped to $140{ }^{\circ} \mathrm{C}\left(10^{\circ} \mathrm{C} / \mathrm{min}\right)$ and further to $240^{\circ} \mathrm{C}\left(40^{\circ} \mathrm{C} / \mathrm{min}\right)$. The injector, transfer line, and electron source were maintained at 200, 280, and $230^{\circ} \mathrm{C}$, respectively. The MSD (electron impact, $70 \mathrm{eV}$ ) was run in the single ion mode (SIM), and the methyl esters of TFA and DFA were quantified using the target ions $m / z 69$ and $m / z 51$, respectively. The overall detection limit for TFA and DFA was $2 \mathrm{ng}$ per sample. The linear working range was up to $4000 \mathrm{ng}$ per sample. With an 
initial water volume of $1 \mathrm{~L}$ and the matrix effect of real-world water samples, the limit of detection for the full method was $10 \mathrm{ng} / \mathrm{L}$.

\subsection{Sampling}

The rainwater samples were collected in open glass beakers for $1 \mathrm{~h}$ (rainwater 1 ) and for $12 \mathrm{~h}$ (rainwater 2), respectively. The unified amounts (sample 1: $1 \mathrm{~L}$, sample 2: $2 \mathrm{~L}$ ) were immediately processed. The surface water samples were taken headspace-free about $50 \mathrm{~cm}$ below the surface in 1 $\mathrm{L}$ glass bottles and cooled to $4-6^{\circ} \mathrm{C}$. In the laboratory, the processing started immediately (between 1 and $12 \mathrm{~h}$ after sampling). The first surface water sample was from the Teltow canal near a sewer drain close by the rainwater sampling point and the contaminated ground water site. The second sample was from a Havel lake in the periphery of Berlin. The ground water samples were taken by pump sampling (35 $\mathrm{m}$ under ground level) from two monitoring wells positioned over the contamination hot spot and the plume (Berlin Oberspree) originating from industrial contamination with R113. The samples were filled headspace-free in $1 \mathrm{~L}$ brown glass bottles, closed, and cooled $\left(4^{\circ} \mathrm{C}\right)$ until processed in the laboratory. A separate sample was used for each determination.

\section{Conclusions}

DFA has so far been largely overlooked in the environment, and may be a further relevant product of the microbial degradation of such CFCs that are firstly metabolized to 1,1-difluoroethenes. To the best of our knowledge, this is the first evidence for a relevant formation pathway of DFA in the environment.

Author Contributions: Conceptualization, U.D. and R.B.; methodology, U.D. and M.K.; validation, M.K. and U.D.; data curation, U.D.; writing—original draft preparation, U.D. and R.B.; writing—review and editing, U.D. and R.B.; visualization, U.D.

Funding: This research received no external funding.

Conflicts of Interest: The authors declare no conflict of interest.

\section{References}

1. $\quad$ Ellis, D.A.; Hanson, M.L.; Sibley, P.K.; Shahid, T.; Fineberg, N.A.; Solomon, K.R.; Muir, D.C.G.; Mabury, S.A. The fate and persistence of trifluoroacetic and chloroacetic acids in pond waters. Chemosphere 2001, 42, 309-318. [CrossRef]

2. Solomon, K.R.; Velders, G.J.M.; Wilson, S.R.; Madronich, S.; Longstreth, J.; Aucamp, P.J.; Bornman, J.F. Sources, fates, toxicity, and risks of trifluoroacetic acid and its salts: Relevance to substances regulated under the Montreal and Kyoto Protocols. J. Toxicol. Environ. Health Part B 2016, 19, 289-304. [CrossRef] [PubMed]

3. Scott, B.F.; Macdonald, R.W.; Kannan, K.; Fisk, A.; Witter, A.; Yamashita, N.; Durham, L.; Spencer, C.; Muir, D.C.G. Trifluoroacetate profiles in the Arctic, Atlantic, and Pacific oceans. Environ. Sci. Technol. 2005, 39, 6555-6560. [CrossRef] [PubMed]

4. Scott, B.F.; Spencer, C.; Marvin, C.H.; MacTavish, D.C.; Muir, D.C.G. Distribution of Haloacetic Acids in the Water Columns of the Laurentian Great Lakes and Lake Malawi. Environ. Sci. Technol. 2002, 36, 1893-1898. [CrossRef] [PubMed]

5. McCulloch, A. Fluorocarbons in the global environment: A review of the important interactions with atmospheric chemistry and physics. J. Fluor. Chem. 2003, 123, 21-29. [CrossRef]

6. Frank, H.; Christoph, E.H.; Holm-Hansen, O.; Bullister, J.F. Trifluoroacetate in Ocean Waters. Environ. Sci. Technol. 2002, 36, 12-15. [CrossRef]

7. Martin, J.W.; Mabury, S.A.; Wong, C.S.; Noventa, F.; Solomon, K.R.; Alaee, M.; Muir, D.C.G. Airborne Haloacetic Acids. Environ. Sci. Technol. 2003, 37, 2889-2897. [CrossRef] [PubMed]

8. Visscher, P.T.; Culbertson, C.W.; Oremland, R.S. Degradation of trifluoroacetate in oxic and anoxic sediments. Nature 1994, 369, 729-731. [CrossRef]

9. Kim, B.R.; Suidan, M.T.; Wallington, T.J.; Du, X. Biodegradability of trifluoroacetic acid. Environ. Eng. Sci. 2000, 17, 337-342. [CrossRef] 
10. Ellis, D.A.; Mabury, C.A.; Jonathan, W.; Martin, J.W.; Muir, D.C.G. Thermolysis of Fluoropolymers as a potential source of halogenated organic acids in the environment. Nature 2001, 412, 321-324. [CrossRef]

11. Ellis, D.A.; Martin, J.W.; Muir, D.C.G.; Mabury, S.A. The use of 19F NMR and mass spectrometry for the elucidation of novel fluorinated acids and atmospheric fluoroacid precursors evolved in the thermolysis of fluoropolymers. Analyst 2003, 128, 756-764. [CrossRef] [PubMed]

12. Pesticide Properties Data Base, University of Hertfordshire. Available online: https://sitem.herts.ac.uk/ aeru/ppdb/en/Reports/2896.htm (accessed on 12 February 2019).

13. Kazil, J.; McKeen, S.; Kim, S.W.; Ahmadov, R.; Grell, G.A.; Talukdar, R.K.; Ravishankara, A.R. Deposition and rainwater concentrations of trifluoroacetic acid in the United States from the use of HFO-1234yf. AGU J. Geophys. Res. Atmos. 2014, 119, 14059-14079. [CrossRef]

14. ISO 20595:2018-01. Water Quality-Determination of Selected Highly Volatile Organic Compounds in Water-Method Using Gas Chromatography and Mass Spectrometry by Static Headspace Technique (HSGC-MS); ISO: Geneva, Switzerland, 2018.

15. Balsiger, C.; Holliger, C.; Höhner, P. Reductive dechlorination of chlorofluorocarbons and hydrochlorofluorocarbons in sewage sludge and aquifer sediment microcosms. Chemosphere 2005, 61, 361-373. [CrossRef] [PubMed]

16. Dohn, D.R.; Leininger, J.R.; Lash, L.H.; Quebbemann, A.J.; Anders, M.W. Nephrotoxicity of S-(2-chloro-1,1,2trifluoroethyl)glutathione and S-(2-chloro-1,1,2-trifluoroethyl)-L-cysteine, the glutathione and cysteine conjugates of chlorotrifluoroethene. J. Pharmacol. Exp. Ther. 1985, 235, 851-857. [PubMed]

17. Morel, G.; Ban, M.; Bonnet, P.; Zissu, D.; Brondeau, M.T. Effect of $\beta$-naphthoflavone and phenobarbital on the nephrotoxicity of chlorotrifluoroethylene and 1,1-dichloro-2,2-difluoroethylene in the rat. J. Appl. Toxicol. 2005, 25, 153-165. [CrossRef]

18. Commandeur, J.N.; Oostendorp, R.A.; Schoofs, P.R.; Xu, B.; Vermeulen, N.P. Nephrotoxicity and hepatotoxicity of 1,1-dichloro-2,2-difluoroethylene in the rat. Indications for differential mechanisms of bioactivation. Biochem. Pharmacol. 1987, 24, 4229-4237. [CrossRef]

19. Dekant, W.; Vamvakas, S.; Berthold, K.; Schmidt, S.; Wild, D.; Henschle, D. Glutathione in bacteria Bacterial $\beta$-lyase mediated cleavage and mutagenicity of cysteine conjugates derived from the nephrocarcinogenic alkenes trichloroethylene, tetrachloroethylene and hexachlorobutadiene. Chem. Biol. Interact. 1986, 60, 31-45. [CrossRef]

20. Lifongo, L.L.; Bowden, D.J.; Brimblecombe, P. Thermal degradation of haloacetic acids in water. Int. J. Phys. Sci. 2010, 5, 738-747. Available online: https://www.researchgate.net/publication/228952048_Thermal_ degradation_of_haloacetic_acids_in_water (accessed on 5 March 2019).

21. Alexandrino, D.A.M.; Ribeiro, I.; Pint, L.M.; Cambra, R.; Oliveira, R.S.; Pereira, F.; Carvalho, M.F. Biodegradation of mono-, di- and trifluoroacetate by microbial cultures with different origins. New Biotechnol. 2017, 43, 23-29. [CrossRef]

22. Oremland, R.S. Microbial Degradation of Atmospheric Halocarbons. In Microbiology of Atmospheric Traces Gases-Sources, Sinks and Global Processes, 1st ed.; Murrell, J.C., Kelly, D.E., Eds.; Springer: Berlin/Heidelberg, Germany, 1996; pp. 85-101. ISBN 978-3-642-64693-5. [CrossRef]

23. Bowden, D.J.; Clegg, S.L.; Brimblecombe, P. The Henry's law constants of the haloacetic acids. J. Atmos. Chem. 1998, 29, 85-107. [CrossRef]

24. Cahill, T.M.; Benesch, J.A.; Gustin, M.S.; Zimmerman, E.J.; Seiber, J.N. Simplified Method for Trace Analysis of Trifluoroacetic Acid in Plant, Soil, and Water Samples Using Headspace Gas Chromatography. Anal. Chem. 1999, 71, 4465-4471. [CrossRef]

(C) 2019 by the authors. Licensee MDPI, Basel, Switzerland. This article is an open access article distributed under the terms and conditions of the Creative Commons Attribution (CC BY) license (http://creativecommons.org/licenses/by/4.0/). 